\title{
Growth and Dispersal of an Erupting Large Herbivore Population in Northern Canada: The Mackenzie Wood Bison (Bison bison athabascae)
}

\author{
C.C. GATES ${ }^{1}$ and N.C. LARTER ${ }^{2}$
}

(Received 6 September 1989; accepted in revised form 11 January 1990)

\begin{abstract}
In 1963, 18 wood bison (Bison bison athabascae) were introduced to the Mackenzie Bison Sanctuary. The population has grown at a mean exponential rate of $r=0.215 \pm 0.007$, reaching 1718 bison $\geq 10$ months of age by April 1987. Analysis of annual population growth revealed a maximum exponential rate of $r=0.267$ in 1975, followed by a declining rate, reaching a low value of $r=0.103$ in 1987 . Selective predation on calves was proposed as a mechanism to explain the declining rate of population growth.

The area occupied by the population increased at an exponential rate of $0.228 \pm 0.017 \mathrm{~km}^{2} \cdot \mathrm{year}^{-1}$. The dispersal of mature males followed a pattern described as an innate process, while dispersal of females and juveniles exhibited characteristics of pressure-threshold dispersal. Key words: erupting population, dispersal, wood bison, Bison bison athabascae, Northwest Territories
\end{abstract}

RÉSUMÉ. En 1963, on a introduit 18 bisons des bois (Bison bison athabascae) dans la Réserve de bisons Mackenzie. La population a connu un taux moyen de croissance exponentielle de $r=0,215 \pm 0,007$, atteignant 1718 bisons qui avaient 10 mois ou plus en avril 1987. Une analyse de la croissance annuelle de la population montre un taux moyen de croissance exponentielle de $r=0,267$ en 1975, suivi d'un taux en baisse jusqu'à $r=0,103$ en 1987. On avance que la prédation sélective s'opérant sur les veaux explique la baisse du taux de croissance de la population.

La superficie occupée par la population s'est accrue à un taux exponentiel de $0,228 \pm 0,017 \mathrm{~km}^{2} \cdot \mathrm{an}^{-1}$. La dispersion des adultes mâles suivait un modèle décrit comme un processus inné, tandis que la dispersion des femelles et des jeunes affichait les caractéristiques d'une dispersion due au seuil de pression.

Mots clés: population en développement rapide, dispersion, bison des bois, Bison bison athabascae, Territoires du Nord-Ouest

Traduit pour le journal par Nésida Loyer.

\section{INTRODUCTION}

The saga of the North American bison (Bison bison) is chronicled as one of the most tragic examples of abuse of wildlife on this continent (Roe, 1970; McHugh, 1972). At the close of the last century the bison was at the brink of extinction. The plains subspecies (B. b. bison) was effectively extinct in Canada by 1885 , and only a few hundred wood bison (B. b. athabascae) remained in the area between Lake Athabasca and Great Slave Lake (Hewitt, 1921). Plains bison recovered rapidly in the early years as a result of government conservation and land protection measures but currently persist largely under private commercial ownership (Renecker et al., 1989).

Until 1957 the wood bison was considered to be extinct owing to hybridization with the 6673 plains bison transplanted into Wood Buffalo National Park between 1925 and 1928 (Banfield and Novakowski, 1960). The recovery of the wood bison since 1963 has been a conservation success (Wood Bison Recovery Team, 1988). Today's wood bison herds originate from a small remnant group of bison discovered in a remote northern part of Wood Buffalo National Park in 1957. Bison were removed from that area to establish herds in the Mackenzie Bison Sanctuary west of Great Slave Lake in 1963 (Novakowski, 1963a,b) and at Elk Island National Park in central Alberta in 1965.

Of the estimated 3000 wood bison in the world, approximately two-thirds are free roaming in the vicinity of the Mackenzie Bison Sanctuary. The growth of the Mackenzie herd has provided an opportunity to examine the pattern of natural geographic and numeric expansion of an erupting large herbivore population subject to predation.

\section{STUDY AREA}

The Mackenzie wood bison herd inhabits an area in the Upper Mackenzie Section of the Boreal Forest Region (Rowe,
1972). The area lies in the emerged bed of a once vast glacial lake (Fig. 1). Glaciation is evident from the occurrence of shallow oriented lakes, drumlins and eskers. Postglacial isostatic uplift raised the shallow lakes, lowered water levels and has caused plant growth to invade lake margins.

Meadow communities are associated with the shallow lake beds. Wet meadows are dominated by varying proportions of slough sedge (Carex atherodes) and water sedge ( $C$. aquatilis). Dry meadows are dominated by varying proportions of slough sedge, several grass species (Calamagrostis spp., Agropyron spp., Phalaris arundinacea, Agrostis scabra) and willows (Salix spp.). Forest fires in 1974 and 1980 modified a fen-dominated area near Mink Lake, improving the habitat for bison. Although meadows constitute the most important habitats for bison, they only represent $6 \%$ of the area (from Mychaisw, 1987).



FIG. 1. Map of the study area. The dotted line indicates the wood bison range. The Mackenzie Bison Sanctuary is outlined by a solid line.

\footnotetext{
${ }^{1}$ Department of Renewable Resources, Government of the Northwest Territories, Fort Smith, Northwest Territories, Canada X0E 0P0

${ }^{2}$ The Ecology Group, Department of Zoology, 2204 Main Mall, University of British Columbia, Vancouver, British Columbia, Canada V6T 1W5

CThe Arctic Institute of North America
} 
Coniferous and mixed coniferous/deciduous forests are the dominant cover types. Extensive stands of jackpine (Pinus banksiana) and spruce (Picea glauca, P. mariana) are found in association with aspen (Populus tremuloides) or balsam poplar ( $P$. balsamifera). Soil moisture conditions and fire history determine the distribution and association of forest stands.

Part of the range occupied by the Mackenzie bison population lies within the Mackenzie Bison Sanctuary, designated under the Northwest Territories Wildlife Act in 1963. The sanctuary provides a useful geographic reference, although it affords no legal protection to the bison or their habitat.

In both 1974 and 1980, large forest fires burned an area near Mink Lake, resulting in a successional association of sedges, grasses and willows suitable for bison. This area of open habitat is approximately $400 \mathrm{~km}^{2}$ and is found in the northwestern part of the bison range.

In addition to bison, the study area supports populations of woodland caribou (Rangifer tarandus caribou) and moose (Alces alces), which serve as alternate prey for wolves (Canis lupus). Wolves are common in the area, although their density is unknown. Black bears (Ursus americanus) are present but are not abundant.

\section{METHODS}

\section{Population Growth}

Total counts of bison were made by aerial surveys of the study area between 1964 and 1987. The census zone increased over time as observations of bison and their signs were seen in adjacent areas. Counts were carried out by various employees of the Northwest Territories Wildlife Service and the Canadian Wildlife Service. Unpublished survey reports are on file with the Northwest Territories Department of Renewable Resources in Yellowknife and Fort Smith.

All censuses but one were conducted during the period January to early April; in 1982 a total count was made in June (T. Chowns, pers. comm. 1984). Prior to 1987 the survey procedure was to search all meadows known to be inhabited by bison and prominent trail systems connecting them. In 1987 , the areas lying between the meadows were searched by flying systematic parallel transects spaced at $3 \mathrm{~km}$ intervals. Altitude was maintained at $300 \mathrm{~m}$ above ground level. When bison tracks or trails were seen in the snow, the vicinity was searched. Bison groups were circled and counted visually. Large groups were photographed to assure a correct count.

Trends in the annual rate of increase were examined using polynomial smoothing to generate a complete time series of population estimates for the 24-year period. Annual exponential rates of increase $(r)$ for each year following introduction were calculated from sequential estimates of population size.

Two transect surveys for moose were carried out during the early years after the bison were introduced. Although transect surveys are known to underestimate moose abundance (Gasaway et al., 1986) and caribou numbers, the surveys provided an index of the abundance of these two species.

\section{Population Structure}

Surveys were carried out between 1984 and 1988 to determine the proportions of adult males, females ( $\geq 2$ years old) and yearlings in the population. Classification criteria followed those outlined by Fuller (1959). Yearlings were bison ranging in age from 9 to 14 months.

Single animals or very small groups were classified from a helicopter flying at low level. Larger aggregations were classified by observers on the ground using spotting scopes. Yearling:cow ratios were determined from late March through August. The adult sex ratio was determined during summer or fall.

\section{Survival Estimates}

Adult survival ( $\geq 1$ year) and calf survival were estimated by successive approximation from a model based on a life table analysis technique described by Taylor and Carley (1988). The derived values for adult and calf survival satisfied the estimated rate of increase for 1986-87 and the observed mean ratio of yearlings: $\geq 2$-year-old cows.

The population was represented by the number of females in each age class between 0 and 25 years old. An initial female population with a stationary age distribution and rate of increase equal to the mean rate observed for the study period 1964-87 was manufactured. Then the observed population statistics for the period 1984-88 and survivorship values were applied. The model population was of the birth-pulse type, with ages of all animals at the birth pulse being taken as an integral number of years. Birth rate was zero for 1- and 2-yearolds, and 0.35 female calves for age classes 3 to 25 , equal to half the observed pregnancy rate in $\geq 2$-year-olds. The model reported rate of increase and yearling:cow ratio after the birth pulse but before the onset of the year's mortality. Forty iterations assured stable reported values.

\section{Reproduction and Condition Evaluation}

Pregnancy was determined by two techniques. Autopsies were conducted on the 28 adult females ( $\geq 2$ years old) culled in both winters. Assays of serum samples for pregnancyspecific protein B (PSPB) were used from 16 chemically immobilized adult female bison (Sasser et al., 1986).

Maximum depth of backfat and Riney kidney fat index (Riney, 1955) were recorded for culled bison. Fat content of femur marrow from culled animals was analyzed following the method of Ransom (1965). A visual assessment of femur marrow colour and consistency provided a crude index of condition (Riney, 1955) for bison presumed to have been killed by wolves. Sampling was carried out in March 1987 and 1988.

\section{Range Expansion and Dispersal}

Animal locations determined from each of 11 censuses were analyzed by the minimum convex polygon method using the Microcomputer Program for the Analysis of Animal Locations (MCPAAL) (Stuwe and Blohowiak, 1985). The analysis provided a measure of the instantaneous dispersion of the bison population at the time of census.

\section{RESULTS}

\section{Population Growth}

In August 1963, 4 adult males, 12 adult females and 4 calf wood bison were released into the wilderness near Fort Providence, thereby establishing the Mackenzie wood bison population. Two bison presumably died soon after release 
(J. Bourque, pers. comm. 1986). Reproductive success was evident in the first year after release; 4 calves were observed in 1964.

Census results showed the population grew at a mean exponential rate of $0.215 \pm 0.007$ (s.e.) during the 24 years after introduction (Fig. 2), reaching a maximum of 1718 bison $\geq 10$ months of age in 1987 .

Observed counts and the vector of population estimates derived by polynomial smoothing were highly correlated ( $\mathrm{r}$ $=0.998$ ). The exponential rate of growth determined from the time series of census estimates varied widely during the first few years after the introduction (Fig. 3). During the years 1975-87, the growth rate declined according to the relationship $\mathrm{Y}=0.382-0.11 \cdot \mathrm{t}\left(\mathrm{r}^{2}=0.86, \mathrm{p}<0.001\right)$, reaching a low value of 0.103 in 1987 .

\section{Population Structure}

The adult sex ratio was similar among three composition surveys $\left(X^{2}=1.94, \mathrm{df}=2, \mathrm{p}>0.05\right)$. The average ratio of males:females in the adult population ( $\geq 2$ years) was 0.76 (Table 1).

The Mackenzie bison population was distributed primarily in two areas. The Mink Lake area (Fig. 1) was colonized by bison in the early 1980 s. In $1987,72 \%$ of the herd was observed in the Mackenzie Bison Sanctuary. Interchange

$(\times 100)$

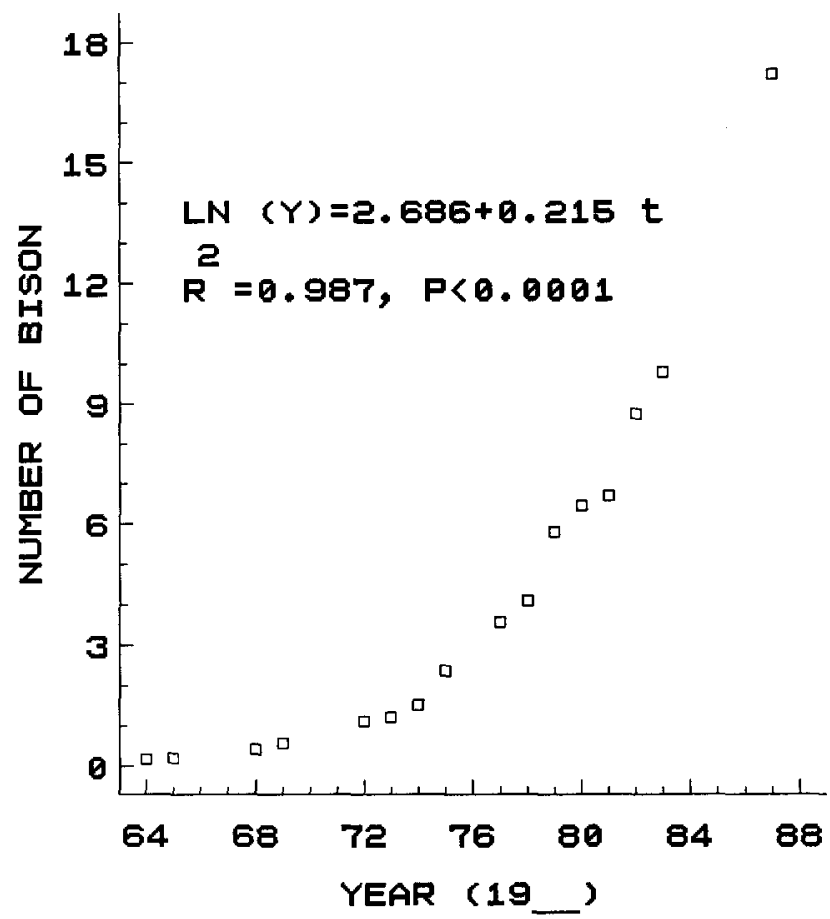

FIG. 2. Growth of the Mackenzie wood bison population from 1964 to 1987.

TABLE 1. Sex ratio of adult bison (M:F $\geq 2$ years of age) in the Mackenzie population

\begin{tabular}{lrccc}
\hline \hline Date & Total & Bulls & Cows & Ratio \\
\hline July 1984 & 618 & 253 & 365 & 0.69 \\
November 1984 & 559 & 243 & 316 & 0.77 \\
June 1988 & 764 & 341 & 423 & 0.81 \\
Total & 1941 & 837 & 1104 & 0.76 \\
\hline \hline
\end{tabular}

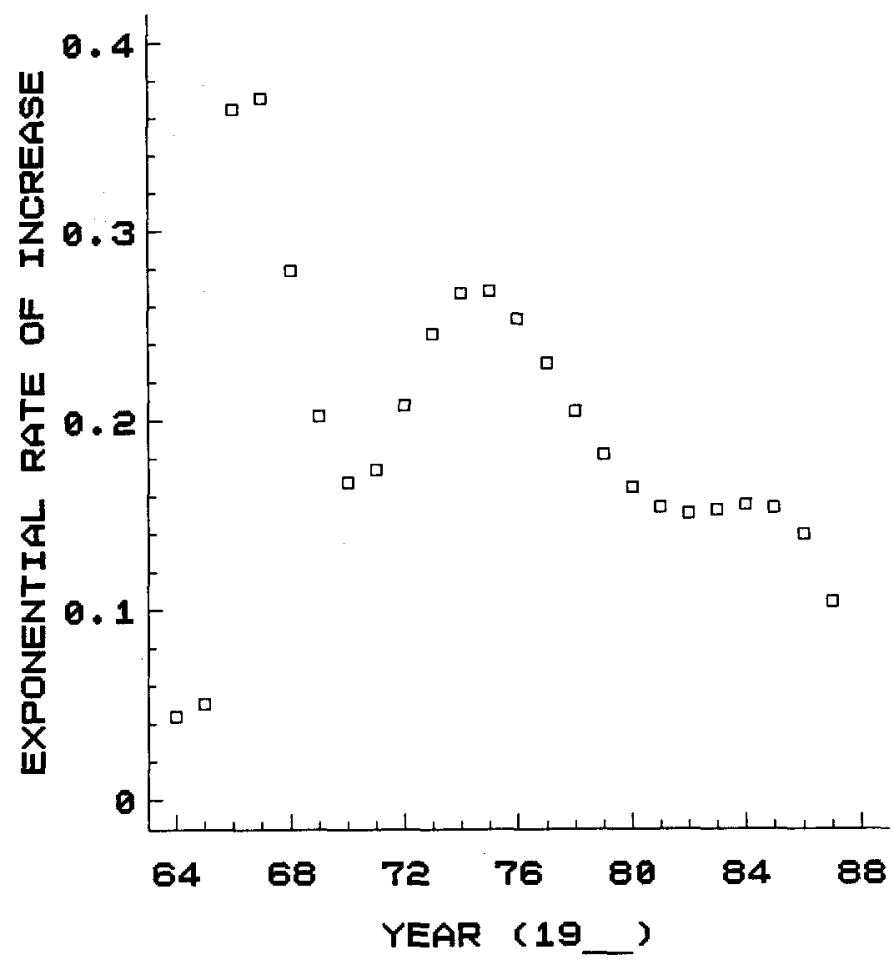

FIG. 3. Changes in the annual exponential rate of growth of the Mackenzie bison population based on a complete series of estimates calculated with a polynomial smoothing procedure.

between the two areas is thought to be minimal (Larter, 1988). Yearling:cow ratios (Table 2) compared between areas showed no significant differences within years. The mean yearling:cow ratio for the entire Mackenzie bison population across years was $0.30 \pm 0.03$ (s.e.), $n=4$.

\section{Survival Estimates}

An adult survival rate of 0.97 and a calf survival rate of 0.55 satisfied the rate of increase for $1986-87$ and the mean yearling:cow ratio observed during 1984-88.

\section{Reproduction and Condition Evaluation}

Nineteen of 28 culled adult female bison ( $\geq 2$ years) were pregnant at autopsy. Twelve of 16 adult females captured by chemical immobilization were determined to be pregnant from the presence of serum PSPB. Only one 2-year-old was included in the sample; it was pregnant and would therefore have calved as a 3-year-old. In addition, one yearling female (18 months old) collected in December 1987 was not pregnant. The overall adult pregnancy rate was $0.70(n=44)$.

TABLE 2. Yearling (male and female): cow ratios for bison in the Mackenzie Bison Sanctuary and Mink Lake areas

\begin{tabular}{|c|c|c|c|c|c|c|}
\hline \multirow[b]{2}{*}{ Date } & \multicolumn{3}{|c|}{ MBS } & \multicolumn{3}{|c|}{ ML } \\
\hline & Cows $\geq 2$ yr & Yearlings & Ratio & Cows $\geq 2 \mathrm{yr}$ & Yearlings & Ratio \\
\hline $\begin{array}{l}\text { March-July } \\
1984 \\
\text { August } 1985\end{array}$ & $\begin{array}{l}439 \\
153\end{array}$ & $\begin{array}{r}112 \\
59\end{array}$ & $\begin{array}{l}0.26 \\
0.39\end{array}$ & $\begin{array}{l}46 \\
29\end{array}$ & $\begin{array}{l}14 \\
10\end{array}$ & $\begin{array}{l}0.30 \\
0.35\end{array}$ \\
\hline $\begin{array}{l}\text { April-August } \\
1986 \\
\text { June } 1988\end{array}$ & $\begin{array}{l}275 \\
319\end{array}$ & $\begin{array}{l}99 \\
71\end{array}$ & $\begin{array}{l}0.36 \\
0.23\end{array}$ & $\begin{array}{r}49 \\
104\end{array}$ & $\begin{array}{r}8 \\
26\end{array}$ & $\begin{array}{l}0.16 \\
0.25\end{array}$ \\
\hline \multicolumn{5}{|c|}{ Mean yearling: cow ratio $0.31 \pm 0.04$} & \multicolumn{2}{|c|}{$0.27 \pm 0.04$} \\
\hline
\end{tabular}


Backfat depth and Riney kidney fat indices were significantly lower in female and calf bison collected in March 1988 than in March 1987 (Table 3) but demonstrated that bison were in good condition for the time of year. The difference in condition of females between years was not confounded by the effects of pregnancy; all females in the 1987 sample were pregnant, and only 1 of the 4 in the 1988 sample was pregnant. The mean percent femoral fat content for 4 calves collected in March 1988 was $56.6 \pm 8.0$ (s.e.). The colour and texture of femur marrow in 15 of 20 wolf-killed calves were similar to culled calves and the marrow was judged to have a similar fat content. Specifically, there was no evidence of severe, prolonged nutritional stress in culled bison or in bison calves killed by predators.

TABLE 3. Comparison ( $t$-test) of backfat depth (mean \pm s.e.) and Riney (1964) kidney fat index (mean \pm s.e.) in wood bison cows and calves (sample size is indicated in brackets)

\begin{tabular}{lrrrc}
\hline \hline & March 1987 & March 1988 & $t$-stat & $P$ \\
\hline Backfat depth (mm) & & & & \\
$\quad$ Cows (6,4) & $20.8 \pm 2.9$ & $4.5 \pm 1.9$ & 4.20 & 0.003 \\
Calves (3,4) & $2.7 \pm 1.2$ & $0.1 \pm 0.1$ & 2.50 & 0.054 \\
Riney index & & & & \\
$\quad$ Cows (6,4) & $2.0 \pm 0.3$ & $0.6 \pm 0.2$ & 3.45 & 0.009 \\
Calves (3,4) & $0.9 \pm 0.2$ & $0.4 \pm 0.1$ & 2.78 & 0.039 \\
\hline \hline
\end{tabular}

\section{Predation and Alternate Prey}

Three transect surveys were conducted in February 1965, December 1971 and April 1987. Results were similar for the two early surveys: moose densities were $0.059 \cdot \mathrm{km}^{-2}$ in 1965 , 87 moose seen along $1834 \mathrm{~km}$ of transect (unpubl. report on file with the Department of Renewable Resources, Government of the N.W.T., Yellowknife), and $0.066 \cdot \mathrm{km}^{-2}$ in 1971,82 moose seen on $1496 \mathrm{~km}$ of transect (unpubl. report on file with the Department of Renewable Resources, Government of the N.W.T., Yellowknife, N.W.T.). Caribou tracks and feeding craters were common. Several other unpublished reports allude to abundant moose and caribou in the area during the 1960s and early $1970 \mathrm{~s}$.

During our 1987 bison survey, we used linear flight paths comparable to the earlier transect surveys. Only one moose was observed on $1075 \mathrm{~km}$ of transect; no caribou tracks or craters were seen. Observations made by researchers travelling on the ground during the past five years are consistent with the trend determined from aerial observations; moose and caribou were rare.

Observations of wolf-killed bison were first recorded in winter 1983. Since then, 24 presumed cases of wolf predation on bison have been recorded, all during winter months. Although wolves were never seen attacking bison, there was sufficient evidence of the presence of wolves in each case to reasonably conclude that wolves were responsible for deaths or wounding. Bruising, lacerations and puncture wounds were consistent with attack patterns reported for wolves (Fuller, 1966; Buskirk and Gipson, 1978). Black bear predation was unlikely because bears den during the winter, when all of the observations were made.

Bison kills were used by wolves in a pattern similar to that reported for moose and elk (Cervus elaphus) by Carbyn (1983). In two cases, bison calves were found alive but severely wounded by wolves and were unable to move away when approached on foot.
Calves were the largest age class in the sample of wolf kills, $20 / 24$, or $83 \%$. The oldest bison killed was a 14-year-old bull (age determined by counting cementum annuli).

\section{Range Expansion and Dispersal}

Range expansion occurred primarily to the west and to a lesser extent to the north (Fig. 4). Occasional sightings of mature male bison have been reported south of the Mackenzie River during the late 1980s.

Shortly after their release, the bison moved to Falaise Lake (Fig. 1). Bison were seen only on Falaise Lake during censuses until 1968. The first evidence of expansion beyond Falaise Lake was recorded in November 1968, when three herds were seen in the vicinity of Calais Lake. In the January 1969 and March 1972 censuses, bison occurred in a similar distribution. In January 1974, all but 6 of 171 bison counted were on Falaise Lake, indicating that bison moved between various parts of their occupied range. Bison were first found on Boulogne Lake in November 1973. In April 1974, bison tracks and feeding craters were seen again on Boulogne Lake. Bison sign, probably a single animal, was also seen north of Caen Lake, the farthest north that bison sign had been observed. Bison were first seen in the southwestern area of the Mackenzie Sanctuary in February 1981 (3 bulls).

Two bison bulls were seen near Mink Lake in August 1980, shortly after the fire was brought under control. In 1981 and 1982, 10 male and 30 unclassified bison were reported respectively. The first evidence of an established breeding population was made during a survey in March 1983; 84 bison were counted, including an unspecified number of calves born the previous year. The number of bison in the Mink Lake area has continued to increase since 1983; the greatest number seen was 487 in April 1987.

In March 1986, 15 bulls were seen in small groups or singles near the north shore of Mills Lake; in April 1987, 23 bulls were seen. The occurrence of mature bulls in peripheral areas

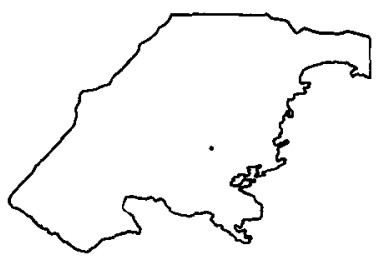

JANUARY 1968

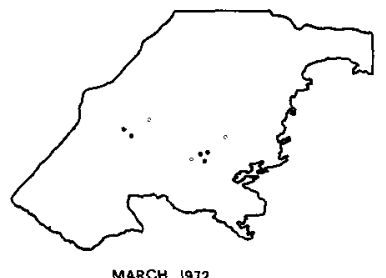

MARCH 1972

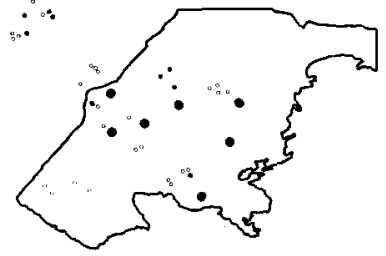

MARCH 1983

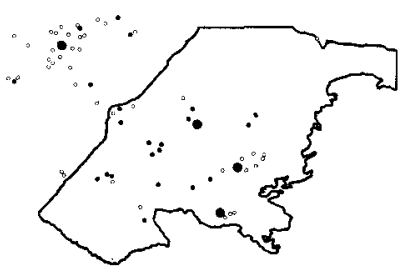

APRIL 1987
FIG. 4. Dispersion of wood bison at the time of census for four years between 1968 and 1987. Open circles represent male-only herds or singles; small dots represent herds of mixed sex and age composition; large dots represent the approximate location of more than one herd. 
is characteristic for the Mackenzie herd. Typically, they have been seen as singles, pairs or in groups of fewer than 5 .

The minimum polygon area occupied by the population increased exponentially between 1968 and 1987 at a rate of $0.228 \pm 0.017$ (s.e.) $\mathrm{km}^{2} \cdot$ year $^{-1}\left(r^{2}=0.953, \mathrm{n}=11\right)$. Range size $\left(\mathrm{km}^{2}\right)$ was related to population size by the equation: $Y=$ $-449.28+4.52 \mathrm{x}, r^{2}=0.929, p<0.001$.

Range expansion was periodic, reflecting two peaks in density, followed by sharp decreases as the population increased its range (Fig. 5). One episode of expansion occurred between 1968 and 1972 as greater use was made of the Mackenzie Bison Sanctuary. Population size increased within the sanctuary until 1980, when a large segment of the population began to make use of the Mink Lake area. The exponential rate of population growth was weakly related to density $\left(r^{2}=0.08, p>0.40\right)$.

\section{DISCUSSION}

Eruptive fluctuations of large herbivores occur in wellestablished populations (Sinclair, 1977, 1979; Houston, 1982) and in populations recently introduced into uninhabited areas (Scheffer, 1951; Klein, 1968; Caughley, 1970a; LeaderWilliams, 1980, 1988; McCullough, 1982). Although the circumstances of liberation or release from a limiting factor may vary, the underlying factor contributing to the initial eruptive growth phase is the large discrepancy between available forage and herbivore density (Riney, 1964). Caughley (1970a) proposed four stages in an eruptive oscillation: an initial period of rapid growth, occurring from the time of
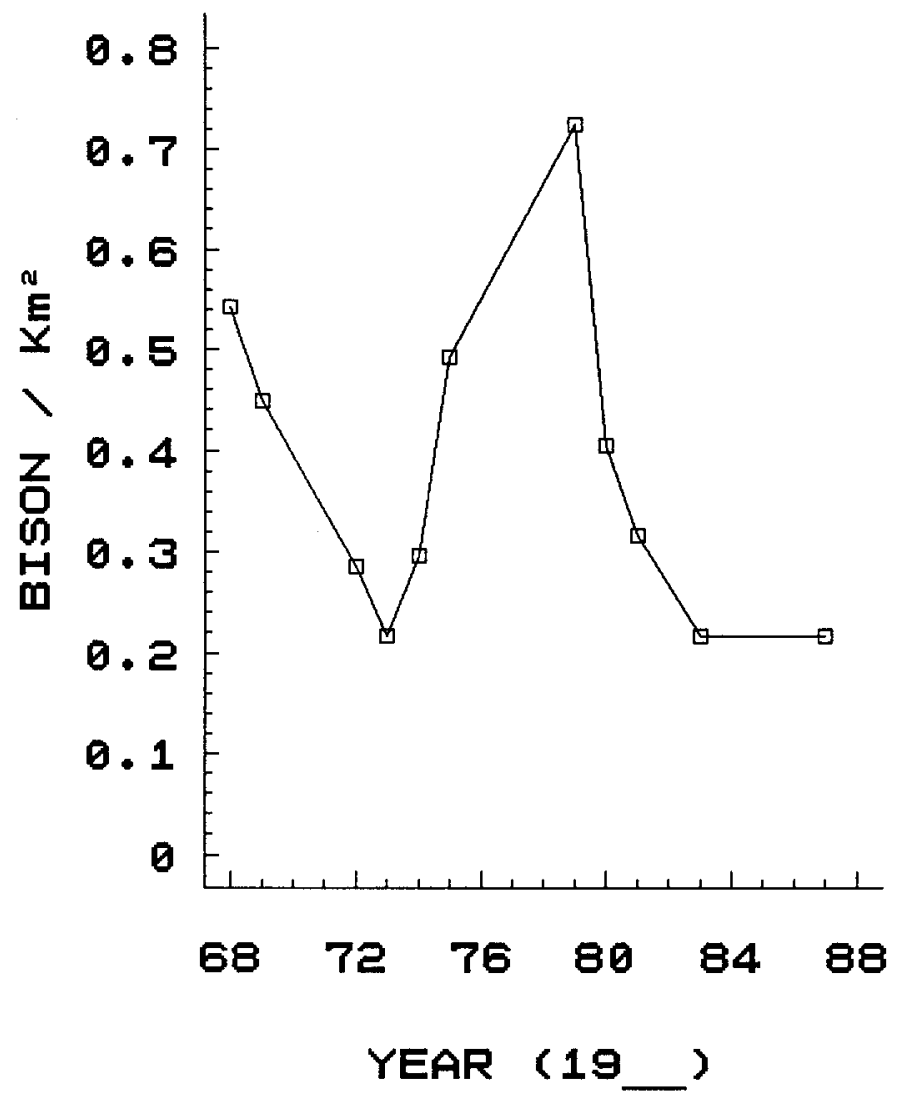

FIG. 5. Trends in the density (bison $\cdot \mathrm{km}^{-2}$ ) of the Mackenzie wood bison population. liberation until peak density is reached; a subsequent period of initial stability; a period of rapid decline; and in stage four, populations oscillate with an amplitude determined by a host of environmental factors.

There has been considerable debate about factors that regulate density or continued growth of large herbivore populations. Dispersal, food availability, predation and disease have received the most attention. Controversy persists around the relative roles of food, predation and weather. Caughley $(1970 \mathrm{a}, 1976)$ held the view that the eruption of ungulates was food related, regardless of predator numbers. An alternative view was that at least some herbivore populations are maintained below levels at which food is limiting either by predation (Mech and Karns, 1977; Caughley et al., 1980; Gasaway et al., 1983; Messier and Crete, 1985) or by disease (Sinclair, 1979; Berry, 1981). In temperate regions, Bergerud has described several systems in which large herbivores were regulated by wolf predation (Bergerud et al., 1983; Bergerud and Elliot, 1986; Bergerud and Ballard, 1988). Messier et al. (1988) suggested that a greater year-round competition for food resources and a greater energy expenditure associated with range expansion were probable regulatory factors for the George River caribou herd in northern Quebec.

For the Mackenzie wood bison population, evidence was found of density dependent range expansion and predation acting to limit density and population growth respectively. Disease was not a factor (Tessaro, 1988).

\section{Population Growth}

The mean exponential growth rate of the Mackenzie bison population $(r=0.215)$ exceeded rates reported for other bison populations. The Wainwright Buffalo Park herd increased at an exponential rate of 0.18 (calculated from data provided in Roe, 1970). The Henry Mountains bison population in Utah grew at a maximum exponential rate of 0.09 between 1977 and 1983 (Van Vuren and Bray, 1986). The maximum exponential rate of 0.27 for the Mackenzie population during the mid-1970s could only have been achieved with little or no mortality in any age class, and with maximum natality rates for mature cows (Calef, 1984).

Such a high level of productivity is only reported for captive populations of bison. Van Vuren and Bray (1986) calculated a mean pregnancy rate of 0.79 within a range of $0.67-0.86$ for five confined herds. The pregnancy rate of 0.70 for Mackenzie 2-year-old and older females was lower than that found in confined herds but was comparable to rates found in four other wild populations (Fuller, 1966; Meagher, 1973; Lott and Galland, 1985; Van Vuren and Bray, 1986).

\section{Dispersal and Range Expansion}

Wood bison use a variety of habitats, exhibiting distinct seasonal patterns (Larter, 1988). Wet meadows and mesic meadows are important winter and summer habitats (Larter, 1988). In winter, bison are found almost exclusively in sedgedominated wet meadows. Other studies have also demonstrated the preference of bison for sedge-dominated habitats during winter (Soper, 1941; Meagher, 1973; Reynolds et al., 1978; Campbell and Hinkes, 1983).

Range expansion of wood bison depends on the distribution of meadow habitats; bison do not occupy areas in which meadows are absent. Nachman (1981) suggested that the average distance between empty patches increases as mean 
population density increases, hence reducing the chance of a migrating individual colonizing an uninhabited patch. It follows that the limit to geographic expansion of the Mackenzie population will be determined by the distribution of unoccupied meadow patches. The north shore of Mills Lake (Fig. 1) represents the last habitat patch of significant size into which bison may expand. Other potential areas north of the present bison distribution are characterized by small, widely spaced patches of meadow.

Dispersal is crucial to the existence of a species in heterogeneous and varying environments (Vance, 1984). Waser (1985) concluded that competition for vital resources limiting to reproduction is the primary factor governing dispersal. Although terminology for dispersal tends to be fluid, conventional models describe the process as "innate" or as "pressure" dispersal. Under innate dispersal, individuals emigrate by more or less random diffusion in response to a genetically predetermined disposition, rather than to environmental conditions (Howard, 1960). Pressure dispersal describes the process whereby individuals disperse only when density reaches a threshold (Caughley, 1977), e.g., in response to competition for food resources. Caughley (1977) also pointed out that innate dispersal often entails a movement many times longer than the average radius of a home range, whereas pressure dispersal more commonly entails a short journey ending when the animal encounters favourable conditions.

In wood bison, both models appear to be operative. First, only mature males (minimum of 5 years old) are found in peripheral habitat patches. Competition for food resources appears an unlikely explanation for this behaviour. Several authors have considered which sex should benefit more from dispersal (Clutton-Brock and Harvey, 1976; Packer, 1979; Greenwood, 1980; Bunnell and Harestad, 1983). Females invest heavily in offspring, while males invest relatively little and compete for access to females. Greater benefits accrue to males gaining access to a large number of females. Because intra-sexual competition is more intense among males than females, many males are denied access to females. During the rut, most mature male bison become solitary and nomadic but attempt to gain access to breeding females by testing the dominance of bulls in female groups (Herrig and Haugen, 1969; Petersburg, 1973; Lott, 1974; Melton et al., 1989). As female/juvenile wood bison aggregations are small, widely scattered and may occupy any habitat type during the rut (Melton et al., 1989), nomadism increases the probability of encountering female groups from which the dominant bull may be displaced. Nomadism is proposed as the mechanism underlying the greater dispersal of mature male wood bison. In addition, owing to their great mobility during the rut, nomadic males are more likely to encounter unoccupied habitat patches, hence the observed distribution of males in patches that are remote from the main occupied areas. This pattern of dispersal conforms to Howard's (1960) definition of innate dispersal. Among other northern large herbivores, male muskox (Ovibos moschatus) appear to exhibit a similar pattern of dispersal (Smith, 1989). Caughley (1970b) observed a distribution pattern in a newly liberated thar (Hemitragus jemlahicus) population that suggests a pattern of dispersal similar to that observed in the Mackenzie wood bison population.

The greater philopatry of female bison can be explained by the greater direct investment of this sex in offspring. They should benefit most from being relatively sedentary, persisting in an area in which the availability and dispersion of forage resources is predictable (Clutton-Brock and Harvey, 1976; Packer, 1979). However, large-scale expansions in range size reflected sudden shifts in the distribution of female/juvenile groups. Two attributes of this pattern of range expansion support the conclusion that the female population was responding to environmental stress. First, major range shifts occurred in two episodes when density was high, one in the early 1970 s and another in the early 1980s. Second, the generalized pattern of increase in range area was exponential, a characteristic of pressure-threshold dispersal (Caughley, 1977). Meagher (1989) attributed range expansion in bison in Yellowstone National Park to stress dispersal brought on by an exceptionally severe winter.

Expansion of the Mackenzie population was density dependent; major shifts occurred when a critical density threshold of $0.5-0.8 \mathrm{bison} \cdot \mathrm{km}^{-2}$ was reached. The most parsimonious explanation for the observed pattern of range expansion is an adaptation to avoid a high level of resource limitation.

The main consequences of dispersal in a patchy environment are: (1) lower population density, (2) higher relative density of resources, (3) greater population stability and (4) maximizing of individual fitness (Lomnicki, 1980). However, the lack of correlation between density and rate of population increase seen in the wood bison indicates that no strong regulatory mechanism was operative up to 1987 .

\section{Predation}

Given a choice, wolves exhibit a preference for moderate size prey species (Murie, 1944; Mech and Frenzel, 1971; Van Ballenberghe et al., 1975; Carbyn, 1983). The relationship between wolves, bison, moose and caribou in the Mackenzie Bison Sanctuary may be similar to the relationship described among moose, caribou and wolves in the Nelchina caribou population (Bergerud and Ballard, 1988) and for wolves, moose and woodland caribou in Alberta (Edmonds, 1988) and British Columbia (Bergerud and Elliot, 1986). Possibly, bison are not diverting predation from moose and caribou; rather, they are exacerbating it.

Wolves associated with the Mackenzie bison herd exhibited a preference for bison calves, a pattern reported for other bison populations (Fuller, 1966; Oosenbrug and Carbyn, 1985; Van Camp, 1987). With an increase in bison calf biomass, wolf density may have increased, exhibiting a functional response caused by improved nutritional status (Packard and Mech, 1980; Keith, 1983; Messier, 1985, 1987). Increased wolf density would lead to higher wolf:moose and wolf:caribou ratios and possibly increased rates of predation on these species. This may explain the perceived decline in moose and caribou numbers.

Furthermore, the rate of wolf predation on the bison population would have increased as alternate prey density decreased and the wolf population increased. We observed a decline in the growth rate of the bison population after 1975. Unfortunately data on yearling:cow ratios prior to the present study are lacking and we cannot confirm a decline in calf survival. Calves were the most common cohort found in wolf kills, with annual mortality from all causes estimated at $45 \%$. Adult survival, estimated from life table analysis, is apparently very high. We suggest that in recent years 
declining calf survival has been the main factor contributing to the decrease in rate of growth of the Mackenzie wood bison herd.

\section{ACKNOWLEDGEMENTS}

We wish to acknowledge the important contributions made by T. Chowns, A. Helmer and L. Penner in establishing the research station from which much of this study was based and their assistance in many aspects of the study. We thank A. Sinclair for assisting with the 1987 census and J. Woods for providing advice on using the MCPAAL program. We are also grateful to $M$. Taylor for providing helpful suggestions on population analysis and to $F$. Messier, M. Ramsay and D. Melton for their helpful editorial comments.

\section{REFERENCES}

BANFIELD, A.W.F., and NOVAKOWSKI, N.S. 1960. The survival of the wood bison (Bison bison athabascae Rhoads) in the Northwest Territories. National Museum of Canada, Natural History Paper No. 8.6 p.

BERGERUD, A.T., and BALLARD, W.B. 1988. Wolf predation on caribou: the Nelchina herd case history, a different interpretation. Journal of Wildlife Management 52:344-357.

BERGERUD, A.T., and ELLIOT, J.P. 1986. Dynamics of caribou and wolves in northern British Columbia. Canadian Journal of Zoology 64:1515-1529.

BERGERUD, A.T., WYETT, W., and SNIDER, B. 1983. The role of wolf predation in limiting a moose population. Journal of Wildlife Management 47:997-998.

BERRY, H.H. 1981. Abnormal levels of disease and predation as limiting factors for wildebeest in the Etosha National Park. Madoqua 12:242-253.

BUNNELL, F., and HARESTAD, A.S. 1983. Dispersal and dispersion of black-tailed deer. Journal of Mammalogy 64:201-209.

BUSKIRK, S.W., and GIPSON, P.S. 1978. Characteristics of wolf attacks on moose in Mount Mckinley National Park, Alaska. Arctic 31:499-502.

CALEF, G. 1984. Population growth in an introduced herd of wood bison (Bison bison athabascae). In: Olson, R., Hastings, R., and Geddes, F., eds. Northern ecology and resource management. Edmonton: University of Alberta Press. 183-200.

CAMPBELL, B.H., and HINKES, M. 1983. Winter diets and habitat use of Alaskan bison after wildfire. Wildlife Society Bulletin 11:16-21.

CARBYN, L.N. 1983. Wolf predation on elk in Riding Mountain National Park, Manitoba. Journal of Wildlife Management 47:963-976.

CAUGHLEY, G. 1970a. Eruption of ungulate populations, with emphasis on Himalayan Thar in New Zealand. Ecology 51:53-72.

1970b. Liberation, dispersal and distribution of Himalayan thar (Hemitragus jemlahicus) in New Zealand. New Zealand Journal of Science 13:220-239.

1976. Plant-herbivore systems. In: May, R.M. Theoretical ecology. Philadelphia: W.B. Saunders Co. 94-113.

1977. Analysis of vertebrate populations. New York: John Wiley and Sons.

, GRIGG, G.C., CAUGHLEY, J., and HILL, G.J.E. 1980. Does dingo predation control the densities of kangaroos and emus? Australian Wildlife Research 7:1-12.

CLUTTON-BROCK, T.H., and HARVEY, P.H. 1976. Evolutionary rules and primate societies. In: Bateson, P.P.G., and Hinde, R.A., eds. Growing points in ethology. Cambridge: Cambridge University Press. 195-237.

EDMONDS, J. 1988. Population status, distributions and movements of woodland caribou in west central Canada. Canadian Journal of Zoology 68:817-826.

FULLER, W.A. 1959. The horns and teeth as indicators of age in bison. Journal of Wildlife Management 23:342-344.

1966. The ecology and management of bison in Wood Buffalo National Park, Canada. Ottawa: Canadian Wildlife Service. Management Bulletin, Series. 1, No. 16.

GASAWAY, W.C., STEPHENSON, R., DAVIS, J., SHEPARD, P., and BURNS, O. 1983. Interrelationships of wolves, prey, and man in interior Alaska. Wildlife Monographs 84:1-50.

GASAWAY, W.C., DUBOIS, S.D., REED, D.J., and HARBO, S.J. 1986. Estimating moose population parameters from aerial surveys. Biological Papers of the University of Alaska, No. 22.

GREENWOOD, P.J. 1980. Mating systems, philopatry and dispersal in birds and mammals. Animal Behaviour 28:1140-1162.
HERRIG, D.M., and HAUGEN, A.O. 1969. Bull bison behaviour traits. Iowa Academy of Science 76:245-262.

HEWITT, C.G. 1921. The conservation of the wildlife of Canada. New York: Scribners.

HOUSTON, D.B. 1982. The northern Yellowstone Elk. New York: Macmillan.

HOWARD, W.E. 1960. Innate and environmental dispersal of individual vertebrates. American Midland Naturalist 63:152-161.

KEITH, L.B. 1983. Population dynamics of wolves. In: Carbyn, L.N., ed. Wolves in Canada and Alaska: their status, biology, and management. Canadian Wildlife Service, Report Series No. 45:66-77.

KLEIN, D.R. 1968. The introduction, increase and crash of reindeer on St. Matthew Island. Journal of Wildlife Management 32:350-367.

LARTER, N.C. 1988. Diet and habitat selection of an erupting wood bison population. M.Sc. thesis, University of British Columbia.

LEADER-WILLIAMS, N. 1980. Population dynamics and mortality of reindeer introduced into South Georgia. Journal of Wildlife Management 44:640-657. Press.

1988. Reindeer of South Georgia. Cambridge: Cambridge University

Press.

differences and patchy environment. Oikos 35:185-193.

LOTT, D.F. 1974. Seasonal and aggressive behaviour of mature male American bison. In: Geist, V., and Walther, F., eds. Behaviour of ungulates in relation to management. Morges, Switzerland: International Union for the Conservation of Nature New Series 1:382-394.

and GALLAND, J.C. 1985. Individual variation in fecundity in an American bison population. Mammalia 49:300-302.

MCCULLOUGH, D.R. 1982. Population growth rate of the George Reserve deer herd. Journal of Wildlife Management 46:1079-1083.

McHUGH, T. 1972. Time of the Buffalo. New York: Alfred A. Knopf.

MEAGHER, M.M. 1973. The bison of Yellowstone National Park. National Park Service, Scientific Monographs, Series No. 1.

1989. Range expansion by bison of Yellowstone National Park. Journal of Mammalogy 70:670-675.

MECH, L.D., and FRENZEL, L.D. 1971. Ecological studies of the timber wolf in northeastern Minnesota. U.S. Department of Agriculture, Forest Service Research Paper NC-52.

MECH, L.D., and KARNS, P.D. 1977. Role of the wolf in deer decline in the Superior National Forest. U.S. Department of Agriculture, Forest Service Research Paper NC-148.

MELTON, D.A., LARTER, N.C., GATES, C.C., and VIRGL, J. 1989. The influence of rut and environmental factors on the behaviour of wood bison. Acta Theriologica 34:175-189.

MESSIER, F. 1985. Social organization, spatial distribution, and population density of wolves in relation to moose density. Canadian Journal of Zoology 63:1068-1077.

1987. Physical condition and blood physiology of wolves in relation to moose density. Canadian Journal of Zoology 65:91-95.

and CRETE, M. 1985. Moose-wolf dynamics and the natural regulation of moose populations. Oecologia 65:503-512.

MESSIER, F., HUOT, J., LE HENAFF, D., and LUTTICH, S. 1988. Demography of the George River caribou herd: evidence of population regulation by forage exploitation and range expansion. Arctic 41:279-287.

MURIE, A. 1944. The wolves of Mount McKinley. Fauna of the National Parks of the United States. Fauna Series No. 5.

MYCHAISW, L. 1987. Primary range survey of the Mackenzie Bison Sanctuary. Unpubl. ms. Available at the Department of Renewable Resources, Yellowknife, Northwest Territories, Canada X1A 2 L9.

NACHMAN, G. 1981. A mathematical model of the functional relationship between density and spatial distribution of a population. Journal of Animal Ecology 50:453-460.

NOVAKOWSKI, N.S. 1963a. Report on the transfer of wood bison, 1963. Unpubl. ms. CWS-35-63. Available at the Canadian Wildlife Service, Edmonton, Alberta, Canada T6B 2X3.

1963b. Wood bison transfer completion report. Unpubl. ms. CWS-35-63. Available at the Canadian Wildlife Service, Edmonton, Alberta, Canada T6B 2X3.

OOSENBRUG, S.M., and CARBYN, L.N. 1985. Wold predation on bison in Wood Buffalo National Park. Unpubl. ms. Available at the Canadian Wildlife Service, Edmonton, Alberta, Canada T6B 2X3.

PACKARD, J.M., and MECH, L.D. 1980. Population regulation in wolves. In: Cohen, M.N., Malpass, R.S., and Klein, G.H., eds. Biosocial mechanisms of population regulation. New Haven: Yale University Press. 135-150.

PACKER, C. 1979. Inter-troop transfer and inbreeding avoidance in Papio anubis. Animal Behaviour 27:1-36. 
PETERSBURG, S.J. 1973. Bull bison behaviour of Wind Cave National Park. M.Sc. thesis, Iowa State University.

RANSOM, A.B. 1965. Kidney and marrow fat as indicators of white-tailed deer condition. Journal of Wildlife Management 29:397-398.

RENECKER, L.A., BLYTH, C., and GATES, C.C. 1989. Game production in western Canada. In: Hudson, R.J., Drew, K.R., Baskin, L.M., Klein, D.R., and Fairall, N., eds. Wildlife Production Systems: Economic Utilization of Wild Ungulates. London: CRC Press.

REYNOLDS, H.W., HANSEN, R.M., and PEDEN, D.G. 1978. Diets of the Slave River Lowland bison, Northwest Territories, Canada. Journal of Wildlife Management 42:581-590.

RINEY, T. 1955. Evaluating condition of free-ranging red deer (Cervus elaphus), with special reference to New Zealand. New Zealand Journal of Science and Technology, Section B 36:429-463.

1964. The impact of introductions of large herbivores on the tropical environment. Morges, Switzerland: International Union for the Conservation of Nature New Series No. 4:4261-4273.

ROE, F.G. 1970. The North American Buffalo: A critical study of the species in its wild state. 2nd ed. Toronto: University of Toronto Press.

ROWE, J.S. 1972. Forest regions of Canada. Department of Environment, Canadian Forestry Service, Publication No. 1300. Ottawa: Queen's Printer.

SASSER, R.G., RUDER, C.A., IVANI, K.A., BUTLER, J.E., and HAMILTON, W.C. 1986. Detection of pregnancy by radio immunoassay of a novel pregnancy-specific protein in serum of cows and a profile of serum concentrations during gestation. Biological Reproduction 35:936-942.

SCHEFFER, V.B. 1951. The rise and fall of a reindeer herd. Scientific Monthly 75:356-362.

SINCLAIR, A.R.E. 1977. The African Buffalo. Chicago: University of Chicago Press.

1979. The eruption of the ruminants. In: Sinclair, A.R.E., and Norton-Griffiths, M., eds. Serengeti: Dynamics of an ecosystem. Chicago: University of Chicago Press.
SMITH, T.E. 1989. The role of bulls in pioneering new habitats in an expanding muskox population on the Seward Peninsula, Alaska. Canadian Journal of Zoology 67:1096-1101.

SOPER, J.D. 1941. History, range and home life of the northern bison. Ecological Monographs 11:349-412.

STUWE, M., and BLOHOWIAK, C.E. 1985. McPAAL: Micro-computer programs for the analysis of animal locations. Front Royal, Va.: Conservation and Research Center, National Zoological Park, Smithsonian Institution.

TAYLOR, M., and CARLEY, J.S. 1988. Life table analysis of age structure populations in seasonal environments. Journal of Wildlife Management 52:366-373.

TESSARO, S.V. 1988. A descriptive and epizootiologic study of brucellosis and tuberculosis in bison in northern Canada. Ph.D. thesis, University of Saskatchewan, Saskatoon.

VAN BALLENBERGHE, V., ERICKSON, A.W., and BYMAN, D. 1975. The ecology of the timber wolf in northeastern Minnesota. Wildlife Monographs No. 43.

VAN CAMP, J. 1987. Predation on bison. In: Reynolds, H.W., and Hawley, A.W.L., eds. Bison ecology in relation to agricultural development in the Slave River Lowlands, NWT. Canadian Wildlife Service Occasional Paper No. 63. Ottawa: Queen's Printer.

VANCE, R.R. 1984. The effect of dispersal on population stability in onespecies, discrete population growth models. American Naturalist 123:230-254.

VAN VUREN, D., and BRAY, M.P. 1986. Population dynamics of bison in the Henry Mountains, Utah. Journal of Mammalogy 67:503-511.

WASER, P.M. 1985. Does competition drive dispersal? Ecology 66:1170-1175.

WOOD BISON RECOVERY TEAM. 1988. Status report on wood bison (Bison bison athabascae) in Canada, 1987. Ottawa: Committee on Endangered Species of Wildlife in Canada, Canadian Wildlife Service. 